\title{
PENGARUH VARIETAS DAN PELEMBABAN PADA VIABILITAS BENIH KEDELAI (Glycinemax[L.] Merrill) PASCASIMPAN TUJUH BELAS BULAN
}

\author{
EFFECT OF VARIETY AND MOISTURE ON SEED VIABILITY OF \\ SOYBEAN (Glycine max [L.] Merrill) POST STORAGE SEVENTEEN \\ MONTHS
}

\author{
Khoirul Akbar Sopian', Niar Nurmauli², Yohanes Cahya Ginting ${ }^{3}$, Ermawati ${ }^{4)}$ \\ Jurusan Agroteknologi, Fakultas Pertanian, Universitas Lampung \\ E-mail: khoirulakbar127@gmail.com
}

Dikirim 5 September 2021, Direvisi 12 Oktober 2021, Disetujui 29 November 2021

\begin{abstract}
Abstrak: Penelitian bertujuan untuk (1) mengetahui perbedaan viabilitas benih tiga varietas kedelai (Anjasmoro, Grobogan, dan Burangrang) pascasimpan tujuh belas bulan, (2) mengetahui perbedaan viabilitas benih yang dilembabkan selama 12 jam dan tidak dilembabkan, dan (3) mengetahui perbedaan viabilitas benih yang dilembabkan atau yang tidak dilembabkan pada masing-masing varietas. Penelitian dilaksanakan di Laboratorium Teknologi Benih dan Pemuliaan Tanaman, Fakultas Pertanian Universitas Lampung pada bulan April sampai dengan Mei 2019. Rancangan percobaan yang digunakan rancangan acak kelompok (RAK) diulang tiga kali. Rancangan perlakuan terdiri atas dua faktor yang disusun secara faktorial $(3 \times 2)$. Faktor pertama adalah varietas kedelai yang terdiri atas tiga varietas, yaitu Anjasmoro $\left(\mathrm{V}_{1}\right)$, Grobogan $\left(\mathrm{V}_{2}\right)$, dan Burangrang $\left(\mathrm{V}_{3}\right)$. Faktor kedua adalah pelembaban benih selama 0 jam $\left(\mathrm{I}_{0}\right)$ dan 12 jam $\left(\mathrm{I}_{1}\right)$. Homogenitas ragam data perlakuan diuji dengan uji Bartlett dan aditivitas data diuji dengan uji Tukey. Jika asumsi terpenuhi maka dilakukan uji lanjut pemisahan nilai tengah menggunakan ortogonal kontras pada taraf nyata 5\%. Hasil penelitian menunjukkan bahwa (1) Varietas Burangrang memiliki viabilitas yang lebih tinggi dibandingkan dengan varietas Grobogan setelah disimpan 17 bulan. Hal tersebut berdasarkan variabel kecepatan perkecambahan dan indeks vigor varietas Burangrang yaitu $32,94 \%$ per etmal dan 0,82; lebih tinggi dibandingkan dengan varietas Grobogan yaitu 29,67\% per etmal dan 0,76. (2) Pelembaban selama 12 jam menghasilkan kecepatan perkecambahan 34,01\% per etmal dan indeks vigor 0,84; lebih tinggi dibandingkan dengan tanpa pelembaban yaitu $28,60 \%$ per etmal dan 0,77 . (3) Viabilitas benih yang dilembabkan atau yang tidak dilembabkan pada masing-masing varietas tidak berbeda.
\end{abstract}

Kata kunci: varietas, benih, pelembaban, viabilitas.

Abstract: The objectives of this study were (1) to determine differences in seed viability of three soybean varieties (Anjasmoro, Grobogan, and Burangrang) after seventeen months of storage, (2) to determine differences in seed viability between moistened seed for 12 hours and unmoisturized seed, and (3) to determine differences in seed viability between moistened and unmoisturized seed in each variety. This research was conducted at the Seed Technology and Plant Breeding Laboratory, Faculty of Agriculture, University of Lampung from April to May 2019.This research was set in Randomized Block Design (RBD) that consist of three replication. The treatment design consisted of two factors that was arranged in a factorial (3x2). The first factor is soybean varieties which consist of three varieties (Anjasmoro (V1), Grobogan (V2), and Burangrang (V3)). The second factor was moistened seed for 0 hours (IO) and 12 hours (II). The data homogeneity was tested by using the Bartlett test and the data additivity was tested by using the Tukey test. If the assumption is fulfilled, then the separation of the mean value was carried out by using orthogonal contrast at 5\% significance level. The results showed that (1) the Burangrang variety had higher viability than the Grobogan variety after being stored for 17 months. This was based on the variable speed of germination and the vigor index of the Burangrang variety, namely $32.94 \%$ per etmal and 0.82; higher than the Grobogan variety, namely 29.67\% per etmal and 0.76. (2) Moisturization for 12 hours resulted a germination rate of $34.01 \%$ per etmal and a vigor index of 0.84; higher than unmoisturized seed, which was $28.60 \%$ per etmal and 0.77 . (3) The viability of moistened and unmoistened seed in each variety did not differ.

Keywords: moisturization, seed, variety, viability. 


\section{PENDAHULUAN}

Penggunaan benih bermutu seringkali terkendala dengan ketersediaannya. Benih harus disimpan untuk pasokan musim tanam berikutnya. Benih kedelai cepat mengalami kemunduran dalam penyimpanan, disebabkan oleh kandungan lemak dan protein yang relatif tinggi. Schwass (1973) dikutip oleh Sutopo (1985), penyimpanan dalam waktu tiga bulan pada suhu kamar $30^{\circ} \mathrm{C}$, benih kedelai tidak dapat mempertahankan viabilitasnya pada kadar air $14 \%$, tetapi bila kadar airnya diturunkan hingga $9 \%$ pada kondisi yang sama maka benih kedelai mampu mempertahankan viabilitasnya selama setahun. Viabilitas yang tetap tinggi setelah benih disimpan merupakan keberhasilan dari penyimpanan.

Benih kedelai termasuk benih ortodoks yaitu benih yang bila disimpan membutuhkan kandungan air yang rendah, sebaliknya bila akan ditanam memerlukan kandungan air yang tinggi. Kandungan air yang tinggi pada saat benih akan ditanam sangat diperlukan untuk meningkatkan aktivitas metabolisme di dalam benih (Mugnisjah dkk., 1994). Untuk meningkatkan aktivitas metabolisme benih yang telah mengalami penyimpanan dapat dilakukan invigorasi sebelum tanam (Rusmin, 2007).

Hasil penelitian menunjukkan benih yang telah mengalami deteriorasi dapat ditingkatkan performanya melalui invigorasi. Invigorasi merupakan upaya memperlakukan benih sebelum tanam dengan menyeimbangkan potensial air benih untuk merangsang metabolisme dalam benih sehingga siap berkecambah, tetapi struktur penting embrio (radikula) beluma muncul. Salah satu perlakuan invigorasi benih yang telah terbukti efektif pada berbagai jenis benih adalah matriconditioning. Matriconditioning adalah perlakuan hidrasi benih terkontrol dengan media padatan lembab yang didominasi oleh kekuatan matriks untuk memperbaiki pertumbuhan bibit (Khan et al. 1992).

Lamanya pelembaban merupakan salah satu faktor yang menentukan efektifitas dari perlakuan osmoconditioning. Lamanya pelembaban berhubungan dengan proses imbibisi dalam benih karena selama pelembaban terjadi perbaikan dan penyelesaian proses metabolisme benih (Nurmauli dan Nurmiaty, 2010). Berdasarkan penelitian Ilyas et. al. (2003), menunjukkan bahwa penggunaan matriconditioning plus inokulan Bradyrhizobium japonicum dan Azospirillum lipoferum pada benih kedelai selama 12 jam mampu meningkatkan pertumbuhan tanaman dan hasil kedelai.

Hasil penelitian Yuanasari $d k k$. (2015), menunjukkan bahwa benih yang direndam menggunakan PEG-6000 selama 12 jam, menghasilkan viabilitas yang lebih baik dibandingkan perendaman 6 dan 18 jam. Hal ini ditunjukkan oleh nilai daya berkecambah yang dihasilkan yaitu sebesar $86,00 \%$. Kemudian hasil tersebut didukung oleh nilai indeks vigor yang tertinggi, yaitu sebesar $60,20 \%$.

Benih kedelai yang telah mengalami kemunduran dan diberikan waktu pelembaban yang tepat, dapat memperbaiki proses metabolisme didalam benih yang akan berdampak pada viabilitas benih tersebut. Penelitian ini menggunakan tiga varietas kedelai yaitu, Anjasmoro, Grobogan, dan Burangrang. Waktu pelembaban yang digunakan yaitu 0 dan 12 jam. Hal ini dilakukan untuk mengetahui apakah varietas kedelai yang mengalami kemunduran karena penyimpanan dapat ditingkatkan viabilitasnya dengan pelembaban benih.

1. Viabilitas Benih selama Penyimpanan

Viabilitas benih adalah daya hidup benih yang dapat ditunjukkan melalui gejala 
pertumbuhan dan gejala metabolisme (Sadjad, 1993). Kemampuan benih untuk tumbuh dan berproduksi normal pada kondisi optimum adalah viabilitas potensial. Kemampuan benih untuk tumbuh dan berproduksi normal pada kondisi suboptimum disebut vigor. Viabilitas potensial dan vigor adalah parameter viabilitas benih (Widajati, dkk., 2013).

Viabilitas merupakan kemampuan benih yang tumbuh normal dalam kondisi tumbuh optimum, penyimpanan adalah salah satu mata rantai terpenting dalam rangkaian kegiatan teknologi benih. Viabilitas benih dalam periode simpan yang sepanjang mungkin dan untuk mempertahankan mutu fisiologi benih selama periode penyimpanan dengan menghambat kecepatan kemunduran benih (deteriorasi) (Sutopo, 2012).

Viabilitas benih merupakan daya kecambah benih yang dapat ditunjukkan melalui gejala metabolisme atau gejala pertumbuhan, selain itu daya kecambah juga merupakan tolok ukur parameter viabilitas potensial benih (Sadjad,1994). Perkecambahan benih mempunyai hubungan erat dengan viabilitas benih dan jumlah benih yang berkecambah merupakan indeks viabilitas benih. Menurut Copeland dan McDonald (2001), viabilitas benih dapat diukur dengan tolok ukur daya berkecambah (germination capacity). Daya berkecambah adalah muncul dan berkembangnya struktur terpenting dari embrio benih serta kecambah tersebut menunjukkan kemampuan untuk berkembang menjadi tanaman normal pada kondisi lingkungan optimum (menguntungkan). Tujuan dari pengujian daya berkecambah adalah memperoleh informasi nilai penanaman benih dilapangan, membandingkan kualitas benih antar seedlot (kelompok benih), menduga storabilitas (daya simpan) benih, dan memenuhi apakah nilai daya berkecambah benih telah memenuhi peraturan yang berlaku (Siregar dan Utami, 2004).

Benih kedelai berviabilitas tinggi sangat diperlukan untuk menghasilkan benih kedelai yang bermutu tinggi pula. Akan tetapi hal ini sering terkendala dengan ketersediaan benih. Penyediaan benih bagi petani untuk musim tanam berikutnya sering mengalami penyimpanan terlebih dahulu sehingga dapat menyebabkan kemunduran mutu benih. Kemunduran suatu benih dapat diterangkan sebagai turunnya kualitas atau viabilitas benih yang mengakibatkan rendahnya vigor dan jeleknya pertumbuhan tanaman serta produksinya (Sutopo, 1985). Untuk itu diperlukan upaya penyimpanan benih, sehingga diperoleh benih kedelai yang tetap berviabilitas tinggi setelah mengalami penyimpanan.

Penyimpanan benih merupakan salah satu penanganan pascapanen kedelai yang penting dari keseluruhan teknologi benih dalam memelihara kualitas benih.Tujuan utama penyimpanan benih adalah untuk mempertahankan viabilitas yang maksimum selama mungkin. Terdapat dua faktor yang yang mempengaruhi viabilitas benih selama penyimpanan, yaitu faktor internal dan eksternal. Faktor internal meliputi jenis dan sifat benih, viabilitas awal benih, dan kandungan air benih (Sutopo, 1985). Faktor eksternal meliputi temperatur, kelembaban, wadah simpan, oksigen, mikroorganisme, dan manusia (Widajati, dkk., 2013). Dengan memperhatikan kedua faktor tersebut selama penyimpanan diharapkan viabilitas benih dapat dipertahankan selama mungkin.

Viabilitas awal benih menentukan periode simpan dari benih tersebut. Benih dengan viabilitas awal yang tinggi lebih tahan terhadap kelembaban serta temperatur tempat penyimpanan yang kurang baik dibandingkan dengan benih yang memiliki viabilitas awal yang rendah (Barton, 1941) yang dikutip oleh Sutopo, 1985). Laju kemunduran benih yang viabilitasnya tinggi juga lebih lambat bila dibandingkan dengan benih berviabilitas rendah. 
Benih kedelai termasuk benih yang cepat mengalami kemunduran terutama jika kondisi lingkungan simpan kurang menguntungkan (suboptimum). Hal ini disebabkan karena kandungan protein yang dimiliki relatif tinggi yaitu $40 \%$, mengakibatkan kadar air benih cepat meningkat. Protein yang bersifat higroskopis, menyebabkan benih mengabsorpsi air lebih banyak (Tatipata, 2008). Benih ortodoks termasuk kedelai umumnya dapat disimpan dalam suhu rendah dan hal ini tidak mempengaruhi viabilitas benihnya. Kandungan air benih yang akan disimpan sebaiknya memiliki kandungan air yang optimal, sehingga benih tersebut dapat disimpan lama tanpa mengalami penurunan viabilitas benih (Sutopo, 1985).

Schwass (1973) dikutip oleh Sutopo (1985) menyatakan bahwa benih kedelai dengan kandungan air 14\% tidak tahan disimpan lebih dari tiga bulan pada temperatur $30^{\circ} \mathrm{C}$, tetapi bila kandungan airnya diturunkan sampai $9 \%$ pada kondisi sama maka benih kedelai tersebut mampu mempertahankan viabilitasnya selama setahun. Viabilitas benih yang tetap tinggi setelah mengalami penyimpanan menggambarkan bahwa vigor benih tersebut masih baik. Vigor adalah kemampuan benih menumbuhkan tanaman normal yang berproduksi normal pada kondisi lapangan yang tidak optimum atau suboptimum. Benih yang mampu menumbuhkan tanaman normal, meskipun kondisi alam tidak optimum atau suboptimum disebut benih memiliki vigor $(\mathrm{Vg})$. Benih yang memiliki vigor tinggi akan menghasilkan produksi di atas normal bila ditumbuhkan pada kondisi optimum. Benih yang memiliki vigor mampu menumbuhkan tanaman normal pada kondisi alam suboptimum dikatakan memiliki vigor kekuatan tumbuh $\left(\mathrm{V}_{\mathrm{KT}}\right)$ yang mengindikasikan bahwa vigor benih mampu menghadapi lahan pertanian yang kondisinya suboptimum (Sadjad, dkk., 1999).

\section{Pelembaban Benih}

Proses awal munculnya tumbuhan kecil dari dalam benih disebut dengan perkecambahan. Syarat untuk terjadi proses perkecambahan adalah kecukupan air untuk melembabkan benih. Perkecambahan dimulai dari proses penyerapan air oleh benih (imbibisi). Menurut Ai dan Ballo (2010), proses penyerapan air oleh benih mengikuti pola triphasic (3 fase). Fase I diawali oleh penyerapan air secara cepat, ini merupakan fase awal penyerapan air yang berlangsung sebagai akibat tarikan terhadap molekul air karena besarnya potensi matrik dari dinding sel dan bahan-bahan lain yang terkandung dalam sel. Selanjutnya pada fase II, penyerapan air berlangsung lambat, karena potensial air benih dengan lingkungannya dalam keadaan seimbang. Fase ini disebut tahap aktivasi. Pada fase III penyerapan air kembali naik, proses perkecambahan telah lengkap dengan ditandai oleh munculnya radikula.

Menurut Powell (1998) dikutip oleh Yuanasari, dkk. (2015), penyerapan air yang diawali secara cepat (fase I), justru dapat berdampak negatif bagi benih yang telah lama disimpan. Benih yang telah lama disimpan mengalami kemunduran mutu, ditandai dengan kerusakan pada membran sel sehingga perlu penanganan khusus terhadap benih yang telah mengalami kemunduran.

Rusmin (2007) berpendapat, solusi yang dapat dilakukan untuk meningkatkan mutu benih yang telah mengalami kemunduran ialah melalui invigorasi. Invigorasi ialah suatu perlakuan fisik atau kimia untuk meningkatkan atau memperbaiki mutu benih yang telah mengalami kemunduran.

Invigorasi didefinisikan sebagai suatu perlakuan pendahuluan pada benih melalui pengontrolan imbibisi air oleh potensial air yang rendah dari media imbibisi. Selama invigorasi terjadi perbaikan fisiologi dan biokimia yang berhubungan dengan 
peningkatan kecepatan tumbuh, peningkatan keserempakan perkecambahan, dan peningkatan potensial perkecambahan (Khan, 1992 yang dikutip oleh Syaiful, dkk., 2012).

Invigorasi didefinisikan sebagai salah satu perlakuan fisik, fisiologis, dan biokimia untuk mengoptimalkan viabilitas benih, sehingga benih mampu tumbuh cepat dan serempak pada kondisi yang beragam (Basu dan Rudrapal, 1982, dikutip oleh Rusmin, 2007). Perlakuan invigorasi dapat berupa hidrasi-dehidrasi, osmoconditioning dan matriconditioning. Penelitian Rusmin menghasilkan peningkatan daya berkecambah jambu mete yang benihnya diberi perlakukan diletakan pada $\mathrm{RH} 100 \%$ dan suhu $42^{\circ} \mathrm{C}$ dari $14,3 \%$ menjadi 89,3\%. Menurut Arif et al. (2014), benih yang diberi perlakuan osmoconditioning terlebih dahulu dapat menyelesaikan proses metabolisme pra perkecambahan sebelum benih ditanam, sehingga membuat benih siap untuk pemunculan radikula (calon akar). Hasilnya adalah benih dapat berkecambah segera setelah ditanam. Selain itu, terjadi juga proses perbaikan metabolisme serta peningkatan integritas membran pada benih selama perlakuan berlangsung.

Munifah (1997) melakukan penelitian tentang invigorasi benih dengan melembabkan benih dalam air (18 jam) pada dua lot benih yang berbeda (mutu sedang dan mutu rendah). Dari hasil penelitian didapatkan bahwa dengan invigorasi menggunakan air mampu meningkatkan daya berkecambah sebesar 7\% pada dua lot benih berbeda dan kecepatan berkecambah sebesar 10,60\%/etmal (mutu sedang) dan 10,32\%/etmal (mutu rendah), mempercepat fase pertumbuhan vegetatif dan generatif, serta mampu meningkatkan komponen hasil, dan mutu benih yang dihasilkan.

3. Pengaruh Invigorasi Terhadap Varietas Kedelai
Penelitian Widajati (1999) terhadap benih kedelai varietas Wilis, perendaman benih menggunakan larutan PEG-6000 konsentrasi $26 \%$ selama 48 jam, mampu meningkatkan nilai keserempakan tumbuh hingga $10 \%$ dengan nilai awal $64,5 \%$. Hasil penelitian Nurmauli dan Nurmiaty (2010) menunjukkan bahwa benih kedelai varietas Anjasmoro yang diberi perlakuan PEG-6000 konsentrasi 10\% selama 4 jam mampu meningkatkan nilai keserempakan tumbuh hingga $18,66 \%$ dengan nilai awal $28 \%$.

Penelitian Anggun (2016) pada lot benih kedelai varietas Dering-1, pelembaban selama 12 jam menghasilkan vigor benih yang lebih tinggi dibandingkan dengan pelembaban selama 24 jam dan tanpa pelembaban. Hal tersebut berdasarkan persentase perkecambahan dan kecepatan perkecambahan benih. Hasil penelitian Yuanasari $d k k$. (2015), menunjukkan bahwa benih kedelai hitam yang direndam menggunakan PEG-6000 selama 12 jam, menghasilkan viabilitas yang lebih baik dibandingkan perendaman 6 dan 18 jam. Hal ini ditunjukkan oleh nilai daya berkecambah yang dihasilkan yaitu sebesar $86,00 \%$. Kemudian hasil tersebut didukung oleh nilai indeks vigor yang tertinggi, yaitu sebesar $60,20 \%$.

\section{METODOLOGI}

Penelitian dilaksanakan di Laboratorium Teknologi Benih dan Pemuliaan Tanaman, Fakultas Pertanian Universitas Lampung pada bulan April sampai dengan Mei 2019. Bahan - bahan yang digunakan adalah varietas kedelai Anjasmoro, Grobogan, Burangrang, air, plastik, aquades, kertas $\mathrm{CD}$, gelas plastik, koran, karet gelang, dan label.

Alat - alat yang digunakan adalah strepler, nampan, gunting, penggaris, oven tipe Memmert, seed counter, timbangan digital, grain moisture tester, alat pengempa kertas, germinator, dan Conductivity meter TDS \& EC. Penelitian ini menggunakan rancangan acak kelompok (RAK). Rancangan 
perlakuan terdiri atas dua faktor. Faktor pertama adalah varietas kedelai yang terdiri atas tiga varietas, yaitu Anjasmoro $\left(\mathrm{V}_{1}\right)$, Grobogan $\left(\mathrm{V}_{2}\right)$, dan Burangrang $\left(\mathrm{V}_{3}\right)$. Faktor kedua adalah pelembaban benih selama 0 jam $\left(\mathrm{I}_{0}\right)$ dan 12 jam $\left(\mathrm{I}_{1}\right)$. Setiap perlakuan diulang sebanyak tiga kali, sehingga terdapat 18 satuan percobaan dalam penelitian ini (Gambar 1). Analisis data menggunakan analisis ragam dengan taraf nyata $5 \%$, sebelumnya homogenitas ragam data perlakuan telah diuji dengan uji Bartlett dan aditivitas data telah diuji dengan uji Tukey. Jika asumsi terpenuhi maka dilakukan uji lanjut pemisahan nilai tengah menggunakan ortogonal kontras pada taraf nyata 5\% (Tabel 1).

Tabel 1. Koefisien ortogonal kontras.

\begin{tabular}{|c|c|c|c|c|c|c|}
\hline \multirow{2}{*}{ Perbandingan } & \multicolumn{2}{|c|}{$V_{1}$} & \multicolumn{2}{|c|}{$\mathrm{V}_{2}$} & \multicolumn{2}{|c|}{$V_{3}$} \\
\hline & $\mathrm{I}_{0}$ & $\mathrm{I}_{1}$ & $\mathrm{I}_{0}$ & $\mathrm{I}_{1}$ & $\mathrm{I}_{0}$ & $\mathrm{I}_{1}$ \\
\hline \multicolumn{7}{|l|}{$\operatorname{Varietas}(\mathrm{V})$} \\
\hline$C_{1}: V_{1} V_{S} V_{2}, V_{3}$ & -2 & -2 & 1 & 1 & 1 & 1 \\
\hline$C_{2}: V_{2} V_{S} V_{3}$ & 0 & 0 & -1 & -1 & 1 & 1 \\
\hline \multicolumn{7}{|l|}{ Pelembaban (I) } \\
\hline $\mathrm{C}_{3}: \mathrm{I}_{0} \mathrm{VS} \mathrm{I}_{1}$ & -1 & 1 & -1 & 1 & -1 & 1 \\
\hline \multicolumn{7}{|l|}{ Interaksi (V X I) } \\
\hline$C_{4}: C_{1} \times C_{3}$ & 2 & -2 & -1 & 1 & -1 & 1 \\
\hline $\mathrm{C}_{5}: \mathrm{C}_{2} \times \mathrm{C}_{3}$ & 0 & 0 & 1 & -1 & -1 & 1 \\
\hline
\end{tabular}

\begin{tabular}{|l|l|}
\hline \begin{tabular}{|l||}
\hline $\mathrm{V}_{1} \mathrm{I}_{1}$ \\
$\mathrm{~V}_{3} \mathrm{I}_{0}$
\end{tabular} & $\mathrm{~V}_{3} \mathrm{I}_{1}$ \\
\hline $\mathrm{V}_{2} \mathrm{I}_{1} \mathrm{I}_{0}$ & $\mathrm{~V}_{1} \mathrm{I}_{0}$ \\
\hline \multicolumn{2}{|c|}{} \\
\hline $\mathrm{V}_{3} \mathrm{I}_{0}$ & $\mathrm{~V}_{2} \mathrm{I}_{0}$ \\
\hline $\mathrm{V}_{1} \mathrm{I}_{1}$ & $\mathrm{~V}_{3} \mathrm{I}_{1}$ \\
\hline $\mathrm{V}_{2} \mathrm{I}_{1}$ & $\mathrm{~V}_{1} \mathrm{I}_{0}$ \\
\hline \multicolumn{2}{|c|}{} \\
\hline $\mathrm{V}_{1} \mathrm{I}_{0}$ & $\mathrm{~V}_{2} \mathrm{I}_{1}$ \\
\hline $\mathrm{V}_{3} \mathrm{I}_{1}$ & $\mathrm{~V}_{2} \mathrm{I}_{0}$ \\
\hline $\mathrm{V}_{1} \mathrm{I}_{1}$ & $\mathrm{~V}_{3} \mathrm{I}_{0}$ \\
\hline
\end{tabular}

Gambar 1. Tata letak percobaan

$$
\begin{array}{cc}
\text { Keterangan: } & \mathrm{V}_{1}=\text { varetas Anjasmoro } \\
& \mathrm{V}_{2}=\text { varetas Grobogan } \\
\mathrm{V}_{3}=\text { varetas Burangrang }
\end{array}
$$

Pelaksanaan penelitian dimulai dari penyiapan benih. Benih yang digunakan adalah benih kedelai varietas Anjasmoro, Grobogan dan Burangrang yang telah disimpan selama tujuh belas bulan di dalam plastik kedap udara. Benih tersebut disimpan didalam kotak kayu berukuran $50 \times 50 \times 50 \mathrm{~cm}$ pada ruangan bersuhu $\left( \pm 16^{0}\right.$ $\mathrm{C}-22^{0} \mathrm{C}$ ) dan RH (45-50\%). Benih yang dibutuhkan untuk pengujian viabilitas benih yaitu pengujian kadar air (8 butir), pengujian persentase daya berkecambah benih (50 butir), pengujian kecepatan perkecambahan benih (50 butir), pengujian indeks vigor (50 butir), dan pengujian daya hantar listrik (25 butir). Proses selanjutnya adalah pelembaban benih. Benih dilembabkan dengan menggunakan kertas CD berukuran $21 \mathrm{~cm} \times 29 \mathrm{~cm}$. Kertas CD yang digunakan sebanyak dua lembar untuk bagian bawah dan dua lembar sebagai penutup. Kertas CD dicelupkan ke dalam wadah yang berisi air lalu dikempa hingga airnya tidak menetes lagi. Benih yang digunakan sebanyak 50 butir untuk setiap perlakuan. Benih disusun pada kertas CD yang sudah lembab, lalu dibiarkan sesuai perlakuan yaitu selama 0 jam $\left(\mathrm{I}_{0}\right)$ dan 12 jam $\left(\mathrm{I}_{1}\right)$.

Variabel pengamatan pada penelitian ini yaitu (1). Persentase daya berkecambah. Pengujian daya berkecambah dilakukan dengan menggunakan Uji Kertas Digulung didirikan dalam Plastik (UKDdP). Pengecambahan benih dilakukan pada alat pengecambahan (germinator) tipe IPB 732A/B. Pengamatan daya berkecambah benih yaitu berdasarkan pada jumlah kecambah normal pada hari ke-5 dan ke-8 setelah tanam (ISTA, 2010). Pada hari terakhir dihitung juga jumlah kecambah abnormal dan benih mati. (2). Kecepatan perkecambahan.

Kecepatan perkecambahan merupakan kecepatan benih untuk berkecambah normal. Kecepatan perkecambahan benih dihitung berdasarkan persentase kecambah normal yang tumbuh pada setiap 24 jam (/etmal). Pengamatan dilakukan pada 1-7 HST (Widajati, 2013). 
(3). Indeks vigor. Indeks vigor merupakan salah satu tolok ukur viabilitas benih yang berdasarkan pada ISTA. Indeks vigor merupakan keseragaman dan kecepatan benih untuk berkecambah dalam waktu tertentu. Pengamatan untuk perhitungan indeks vigor dilakukan pada pengamatan ke-1 (hari ke-5) dengan menghitung jumlah kecambah normal. (4). Potensi tumbuh maksimum (PTM) adalah kemampuan benih untuk tumbuh dalam keadaan normal maupun abnormal dengan batas minimal keluarnya akar dari benih. Potensi tumbuh maksimum dihitung berdasarkan jumlah kecambah normal dan abnormal yang tumbuh sampai akhir pengamatan. (5). Kadar air benih. Pengujian kadar air dapat dilakukan secara langsung dengan cara pengovenan dan secara tidak langsung dengan alat grain moisture tester. Dalam penelitian ini metode yang digunakan adalah metode tidak langsung yaitu dengan alat grain moisture tester dengan satu sampel menggunakan 8 butir benih kedelai yang dimasukkan kedalam alat dan tuas diputar hingga benih hancur dan ditekan tombol measurese hingga nilai kadar air tertera pada alat. (6). Bobot kering kecambah normal. Kecambah normal dari hasil perkecambahan benih dipisahkan dari kotiledon, dimasukkan kedalam amplop kertas, dioven pada suhu $80^{\circ} \mathrm{C}$ selama $3 \mathrm{x}$ 24 jam kemudian ditimbang bobot kering kecambah menggunakan timbangan ohause. Bobot kering kecambah normal didapat dari hasil pembagian antara bobot kering kecambah yang didapat dengan jumlah kecambah normal yang tumbuh. Satuan bobot kering kecambah normal adalah miligram (mg).

(7). Daya hantar listrik. Pengujian daya hantar listrik merupakan metode yang digunakan untuk mengukur tingkat kebocoran membran sel. Pengukuran nilai daya hantar listrik dilakukan dengan cara merendam 25 butir benih kedelai ke dalam $110 \mathrm{ml}$ air aquadest selama 24 jam.
Pengukuran DHL dilakukan dengan mengukur elektrolit yang bocor dari jaringan pada benih yang terlarut ke dalam air rendaman benih dengan menggunakan alat conductivity meter TDS \& EC. Penggunaan alat tersebut yaitu dengan cara memasukkan dip cell ke dalam air rendaman benih. Nilai konduktivitasnya akan terbaca dengan satuan $\mu \mathrm{S} / \mathrm{cm}$. Nilai konduktivitas larutan blanko diperoleh dari pengukura terhadap larutan yang telah didiamkan selama 24 jam tanpa benih kedelai. Nilai blanko tersebut sebagai nilai kontrol konduktivitas listrik.

\section{HASIL DAN PEMBAHASAN}

Hasil penelitian menunjukkan bahwa perbedaan varietas kedelai dan lama pelembaban tidak berpengaruh terhadap daya berkecambah benih pascasimpan tujuh belas bulan. Daya berkecambah benih yang dilembabkan atau yang tidak dilembabkan pada masing-masing varietas tidak berbeda (Tabel 2). Rata-rata umum nilai daya berkecambah benih varietas Anjasmoro, Grobogan, dan Burangrang adalah $85,6 \%$. Pada variabel kecepatan perkecambahan, varietas Burangrang memiliki kecepatan perkecambahan yang lebih tinggi dari varietas Grobogan dengan selisih 9,94\%. Pelembaban selama 12 jam lebih tinggi daripada tanpa pelembaban dengan selisih 15,90\% untuk kecepatan perkecambahan benih. Tidak terdapat perbedaan kecepatan perkecambahan benih yang dilembabkan atau yang tidak dilembabkan pada masing-masing varietas (Tabel 3).

Hasil penelitian menunjukkan bahwa varietas Burangrang memiliki indeks vigor yang lebih tinggi dari varietas Grobogan dengan selisih $8,11 \%$. Pelembaban selama 12 jam lebih tinggi dari tanpa pelembaban, selisih yang dihasilkan sebesar 9,21\%. Tidak terdapat perbedaan indeks vigor benih yang dilembabkan atau yang tidak dilembabkan pada masing-masing varietas (Tabel 4). Pada variabel potensi tumbuh 
maksimum, perbedaan varietas kedelai, lama pelembaban, dan interaksi keduanya tidak berpengaruh terhadap potensi tumbuh maksimum benih (Tabel 5). Rata-rata umum nilai potensi tumbuh maksimum varietas Anjasmoro, Grobogan dan Burangrang adalah 92,2\%.

Pada pengujian kadar air benih, varietas Anjasmoro memiliki kadar air awal yang lebih tinggi dari varietas Grobogan dan Burangrang. Kadar air benih varietas Anjasmoro, Grobogan dan Burangrang secara berturut-turut adalah 11,37; 10,53; dan 10,67\%. Berdasarkan hasil yang didapatkan, varietas Grobogan dan Burangrang mempunyai bobot kering kecambah nomal yang lebih tinggi dari varietas Anjasmoro dengan selisih 9,26\%. Varietas Grobogan mempunyai bobot kering kecambah normal yang lebih tinggi 19,98\% dari varietas Burangrang. Lama pelembaban tidak berpengaruh terhadap bobot kering kecambah normal, dan tidak terdapat perbedaan bobot kering kecambah normal benih yang dilembabkan atau yang tidak dilembabkan pada masing-masing varietas (Tabel 6). Berdasarkan penelitian yang dilakukan, perbedaan varietas kedelai, lama pelembaban, dan interaksinya tidak berbeda pada daya hantar listrik (Tabel 7). Rata-rata umum nilai daya hantar listrik benih varietas Anjasmoro, Grobogan, dan Burangrang adalah 177,1 $\mu \mathrm{S} / \mathrm{cm}$.

Tabel 2. Pengaruh varietas dan pelembaban pada daya berkecambah benih kedelai.

\begin{tabular}{|c|c|c|c|}
\hline \multirow[b]{2}{*}{ Perbandingan } & \multicolumn{3}{|c|}{ Daya Berkecambah } \\
\hline & Q & $\begin{array}{c}\text { Selisih } \\
(\%)\end{array}$ & F-hitung \\
\hline \multicolumn{4}{|l|}{ Varietas $(\mathrm{V})$} \\
\hline $\mathrm{Cl}$ : Anjasmoro vs Grobogan, Burangrang & -34 & & 0,59 in \\
\hline $\mathrm{C} 2$ : Grobogan vs Burangrang & 42 & & 2,68 in \\
\hline Pelembaban (I) & & & \\
\hline $\begin{array}{l}\text { C3: Tanpa pelembaban vs pelembaban } 12 \text { jam } \\
\text { VXI }\end{array}$ & 57 & & 3,29 tn \\
\hline $\mathrm{C} 4: \mathrm{C} 1 \mathrm{XC} 3$ & -18 & & 0,16 th \\
\hline $\mathrm{C} 5: \mathrm{C} 2 \mathrm{XC} 3$ & -10 & & 0,15 tin \\
\hline
\end{tabular}

Tabel 3. Pengaruh varietas dan pelembaban pada kecepatan perkecambahan benih kedelai.

\begin{tabular}{lrrr}
\hline \multirow{2}{*}{ Perbandingan } & \multicolumn{3}{c}{ Kecepatan perkecambahan } \\
\cline { 2 - 4 } & $Q$ & $\begin{array}{c}\text { Selisih } \\
(\%)\end{array}$ & F-hitung \\
\hline Varietas (V) & & & \\
C1: Anjasmoro vs Grobogan, Burangrang & $-0,01$ & & 0,00 th \\
C2: Grobogan vs Burangrang & 19,66 & 9,94 & 20,53 \\
Pelembaban (I) & & & \\
C3: Tanpa pelembaban vs pelembaban 12 jam & 48,66 & 15,90 & 83,87 \\
VXI & & & \\
C4: C1 X C3 & $-3,04$ & & 0,16 th \\
C5: C2 X C3 & 5,96 & & 1,89 tn \\
\hline
\end{tabular}

Tabel 4. Pengaruh varietas dan pelembaban pada indeks vigor benih kedelai.

\begin{tabular}{|c|c|c|c|}
\hline \multirow{2}{*}{ Perbandingan } & \multicolumn{3}{|c|}{ Indeks vigor } \\
\hline & Q & Selisih $(\%)$ & F-hitung \\
\hline \multicolumn{4}{|l|}{$\operatorname{Varietas}(\mathrm{V})$} \\
\hline $\mathrm{Cl}$ : Anjasmoro vs Grobogan, Burangrang & $-0,62$ & & 4,30 tif \\
\hline $\mathrm{C} 2$ : Grobogan vs Burangrang & 0,40 & 8,11 & $5,36^{*}$ \\
\hline \multicolumn{4}{|l|}{ Pelembaban (I) } \\
\hline C3: Tanpa pelembaban vs pelembaban 12 jam & 0,70 & 9,21 & $10,95 *$ \\
\hline \multicolumn{4}{|l|}{ VXI } \\
\hline $\mathrm{C} 4 \mathrm{ClXC3}$ & $-0,02$ & & 0,00 tit \\
\hline C5: $\mathrm{C} 2 \mathrm{XC3}$ & 0,12 & & 0,48 in \\
\hline
\end{tabular}

Tabel 5. Pengaruh varietas dan pelembaban pada potensi tumbuh maksimum benih kedelai.

\begin{tabular}{|c|c|c|c|}
\hline \multirow{2}{*}{ Perbandingan } & \multicolumn{3}{|c|}{ PTM } \\
\hline & Q & Selisih (\%) & F-hitung \\
\hline \multicolumn{4}{|l|}{ Varietas (V) } \\
\hline $\mathrm{Cl}$ : Anjasmoro vs Grobogan, Burangrang & 4 & & 0,02 in \\
\hline $\mathrm{C} 2$ : Grobogan us Burangrang & 20 & & 1,24 th \\
\hline \multicolumn{4}{|l|}{ Pelembaban (I) } \\
\hline C3: Tanpa pelembaban vs pelembaban 12 jam & 32 & & 2,12 th \\
\hline \multicolumn{4}{|l|}{ VXI } \\
\hline $\mathrm{C} 4: \mathrm{ClXC3}$ & .16 & & 0,26 th \\
\hline $\mathrm{C} 5: \mathrm{C} \times \mathrm{XC} 3$ & 4 & & 0,05 in \\
\hline
\end{tabular}


Tabel 6. Pengaruh varietas dan pelembaban pada bobot kering kecambah normal.

\begin{tabular}{lrrr}
\hline \multirow{2}{*}{ Perbandingan } & \multicolumn{3}{c}{ BKKN } \\
\cline { 2 - 4 } & Q & $\begin{array}{c}\text { Selish } \\
(\%)\end{array}$ & F-hitung \\
\hline Varietas (V) & & \\
C1: Anjasmoro vs Grobogan, Burangrang & 0,029 & 9,26 & 12,87 \\
C2: Grobogan vs Burangrang & $-0,028$ & 19,98 & 37,15 \\
Pelembaban (I) & & \\
C3: Tanpa pelembaban vs pelembaban 12 jam & 0,006 & 1,25 th \\
VXI & & \\
C4: Cl X C3 & $-0,013$ & 2,46 tn \\
C5: C2XC3 & 0,002 & 0,13 tut \\
\hline
\end{tabular}

Tabel 7. Pengaruh varietas dan pelembaban pada daya hantar listrik benih kedelai.

\begin{tabular}{|c|c|c|c|}
\hline \multirow[b]{2}{*}{ Perbandingan } & \multicolumn{3}{|c|}{ Daya hantar listrik } \\
\hline & Q & $\begin{array}{c}\text { Selisih } \\
(\%)\end{array}$ & F-hitung \\
\hline \multicolumn{4}{|l|}{ Varietas $(\mathrm{V})$} \\
\hline $\mathrm{Cl}$ : Anjasmoro vs Grobogan, Burangrang & 60,75 & & 0,16 in \\
\hline $\mathrm{C}$ : Grobogan us Burangrang & $-133,45$ & & $2,26^{\text {tn }}$ \\
\hline \multicolumn{4}{|l|}{ Pelembaban (I) } \\
\hline $\begin{array}{l}\text { C3: Tanpa pelembaban vs pelembaban } 12 \text { jam } \\
\text { VXI }\end{array}$ & 9,05 & & 0,01 in \\
\hline $\mathrm{C} 4: \mathrm{ClXC} 3$ & 100,25 & & 0,43 in \\
\hline $\mathrm{C} 5: \mathrm{C} 2 \mathrm{XC} 3$ & $-64,15$ & & 0,52 in \\
\hline
\end{tabular}

Menurut Sadjad (1993), viabilitas benih dapat dilihat dari persentase daya berkecambah, kecepatan perkecambahan, dan bobot kering kecambah normal. Variabel indeks vigor, potensi tumbuh maksimum, kadar air, dan daya hantar listrik merupakan variabel pendukung viabilitas benih. Viabilitas benih merupakan daya kecambah benih yang dapat ditunjukkan melalui gejala metabolisme atau gejala pertumbuhan, selain itu daya kecambah juga merupakan tolok ukur parameter viabilitas potensial benih (Sadjad,1994). Perkecambahan benih mempunyai hubungan erat dengan viabilitas benih dan jumlah benih yang berkecambah merupakan indeks viabilitas benih.

Hasil penelitian menujukkan bahwa perbedaan varietas, lama pelembaban dan interaksinya tidak berbeda pada daya berkecambah benih. Varietas kedelai Anjasmoro, Grobogan, dan Burangrang memiliki rata-rata daya berkecambah berturut-turut sebesar $87,5 \%, 81,2 \%$, dan $88,2 \%$. Benih tanpa pelembaban menghasilkan rata-rata daya berkecambah sebesar 82,4\% dan dengan pelembaban 12 jam menghasilkan rata-rata daya berkecambah sebesar $88,8 \%$. Berdasarkan hal tersebut, daya berkecambah benih pada masing-masing varietas masih tinggi. Hal tersebut diduga menjadi penyebab lama pelembaban tidak berpengaruh dan interaksinya tidak berbeda nyata untuk semua variabel pengamatan. Selain daya berkecambah yang masih tinggi, lingkungan simpan yang baik diduga menjadi penyebab tidak nyatanya interaksi antara varietas dan pelembaban. Menurut Sutopo (1985), tujuan utama penyimpanan benih adalah untuk mempertahankan viabilitas yang maksimum selama mungkin. Terdapat dua faktor yang yang mempengaruhi viabilitas benih selama penyimpanan, yaitu faktor internal dan eksternal. Faktor internal meliputi jenis dan sifat benih, viabilitas awal benih, dan kandungan air benih. Faktor eksternal meliputi temperatur, kelembaban, wadah simpan, oksigen, mikroorganisme, dan manusia.

Kecepatan perkecambahan yang dihasilkan benih varietas Anjasmoro, Grobogan, dan Burangrang secara berturutturut adalah sebesar $31,31 \%$ per etmal, $29,67 \%$ per etmal, dan $32,94 \%$ per etmal. Varietas Burangrang memiliki viabilitas yang lebih tinggi dari varietas Grobogan dengan selisih kecepatan perkecambahan $3,27 \%$ per etmal. Pelembaban selama 12 jam mampu meningkatkan kecepatan perkecambahan benih dari $28,60 \%$ per etmal menjadi $34,01 \%$ per etmal. Hasil tersebut sejalan dengan penelitian Anggun (2016) yang menyatakan bahwa pelembaban selama 12 jam pada lot benih kedelai varietas Dering-1 menghasilkan vigor benih yang lebih tinggi dibandingkan 
dengan pelembaban selama 24 jam dan tanpa pelembaban berdasarkan daya berkecambah dan kecepatan perkecambahan benih.

Pelembaban merupakan cara untuk memenuhi kebutuhan air benih yang digunakan untuk merangsang aktivitas metabolisme dalam benih sehingga benih siap untuk pemunculan radikula (calon akar) dan benih dapat segera berkecambah setelah ditanam. Kandungan air yang tinggi pada saat benih akan ditanam sangat diperlukan untuk meningkatkan aktivitas metabolisme di dalam benih (Mugnisjah dkk., 1994). Keberhasilan dari pelembaban benih bergantung pada kualitas benih yang dapat dilihat dari status viabilitasnya. Widajati (1999) menyatakan bahwa, perlakuan osmoconditioning secara efektif berpengaruh pada benih yang telah mengalami kemunduran, baik akibat lama penyimpanan (alami) maupun buatan (devigorasi), yaitu dengan nilai daya berkecambah berkisar antara 72 hingga 90\% (bermutu sedang). Osmoconditioning tidak berpengaruh pada benih yang daya berkecambahnya masih tinggi (>90\%), karena kondisi organel-organel masih baik, demikian pula aktifitas enzim-enzim masih tinggi. Pada benih yang daya berkecambahnya rendah $(<72 \%)$, organelorganel sel pada benih sudah terlalu rusak, sehingga sulit untuk dipulihkan kembali.

Menurut Arif et al. (2014), benih yang diberi perlakuan osmoconditioning terlebih dahulu dapat menyelesaikan proses metabolisme pra perkecambahan sebelum benih ditanam, sehingga membuat benih siap untuk pemunculan radikula (calon akar). Hasilnya adalah benih dapat berkecambah segera setelah ditanam. Selain itu, terjadi juga proses perbaikan metabolisme serta peningkatan integritas membran pada benih selama perlakuan berlangsung.

Bobot kering kecambah normal mengindikasikan cadangan makanan pada kandungan benih. Benih kedelai varietas
Anjasmoro, Grobogan, dan Burangrang secara berturut-turut memiliki rata-rata bobot kering kecambah normal sebesar $0,0235 \mathrm{mg}, 0,0283 \mathrm{mg}$, dan $0,0236 \mathrm{mg}$. Viabilitas benih varietas Grobogan dan Burangrang lebih tinggi dari varietas Anjasmoro, selisih bobot kering kecambah normal yang dihasilkan sebesar $0,0025 \mathrm{mg}$ dan viabilitas benih varietas Grobogan lebih tinggi dari varietas Burangrang dengan selisih bobot kering kecambah normal yaitu $0,0047 \mathrm{mg}$. Pada saat proses perkecambahan, terjadi perombakan asimilat atau cadangan makanan oleh enzim-enzim serta naiknya tingkat respirasi benih (Sutopo, 2002). Peningkatan laju respirasi akan mengaktifkan enzim-enzim yang terdapat dalam benih. Enzim amilase merombak pati menjadi gula (glukosa, fruktosa, sukrosa), lipase yang merombak lemak menjadi gliserol dan asam lemak, dan protase yang merombak protein menjadi asam amino. Saat terjadi respirasi juga terbentuk air dan $\mathrm{CO}_{2}$. Pada hasil penelitian, lama pelembaban tidak menghasilkan bobot kering kecambah normal yang berbeda. Hal tersebut diduga berhubungan dengan kadar air yang tinggi dari hasil respirasi sehingga saat kecambah dikeringkan, bobot kering kecambah normal akan semakin berukurang akibat kehilangan air.

Hasil penelitian menunjukkan bahwa benih kedelai varietas Burangrang memiliki indeks vigor 0,82 ; lebih tinggi dari varietas Grobogan dengan indeks vigor 0,76. Pelembaban selama 12 jam mampu meningkatkan indeks vigor benih dari 0,77 menjadi 0,84. Perbedaan varietas, lama pelembaban, dan interaksi keduanya tidak bebeda pada potensi tumbuh maksimum benih. Pada daya hantar listrik, perbedaan varietas, lama pelembaban, dan interaksi keduanya tidak bebeda nyata. Daya hantar listrik merupakan uji kebocoran membrane sel dalam melepasakan ion-ion sel yang menunjukan kerusakan intregritas membrane sel. 
Hasil penelitian menunjukkan bahwa varietas Anjasmoro memiliki kadar air $11,37 \%$, lebih tinggi dari varietas Grobogan dan Burangrang yaitu 10,53\% dan 10,67\% . Hukum-hukum Harrington yang menggambarkan hubungan antara kadar air dan suhu ruang penyimpanan terhadap umur simpan benih yaitu setiap penurunan suhu ruang simpan sebesar $5^{\circ} \mathrm{C}$, umur simpan benih akan bertambah menjadi dua kali lipat. Setiap penurunan kadar air benih $1 \%$, umur simpan benih akan bertambah menjadi dua kali lipat. Hukum ini berlaku kelembaban relatif ruang penyimpanan berkisar antara $15 \%$ $70 \%$, dengan suhu antara $0^{\circ} \mathrm{C}-30^{\circ} \mathrm{C}$, dan kadar air benih antara 4\%-14\% (Kuswanto, 2003). Semakin tinggi kandungan air benih, makin tidak tahan benih terebut untuk disimpan lama. Kenaikan $1 \%$ dari kandungan air benih, umur benih akan menjadi setengahnya. Hukum ini berlaku untuk kandungan air benih antara $5 \%$ dan 14\%, karena dibawah $5 \%$ kecepatan menuanya umur benih dapat meningkat disebabkan oleh autoksidasi lipid di dalam benih sedangkan diatas $14 \%$ akan terdapat cendawan gudang yang merusak kapasitas perkecambahan benih (Hong, 2005).

Kadar air benih yang tinggi mendorong terciptanya kondisi yang mempercepat laju kerusakan benih, akibat terjadinya proses metabolisme dan respirasi. Laju repirasi yang tinggi dapat mempercepat hilangnya viabilitas benih. Roberts (1972) menyatakan bahwa hilangnya viabilitas benih adalah karena berkurangnya bahan cadangan makanan melalui respirasi. Disamping itu, pada kadar air yang tinggi mikroorganisme akan tumbuh aktif dan berkembang merusak embrio. Agrawal (1980) menyatakan bahwa untuk benih ortodoks pada kadar air $12-14 \%$ viabilitas benih menurun dengan cepat, disamping itu cendawan juga tumbuh dan berkembang serta merusak benih dengan cepat.
Manfaat penelitian ini yaitu diperoleh rekomendasi varietas unggul yang memiliki viabilitas paling tinggi meskipun telah disimpan selama 17 bulan yang dapat digunakan produsen benih sebagai acuan untuk pertanaman berikutnya. Dalam penelitian ini varietas Burangrang memiliki viabilitas paling tinggi yaitu dengan selisih 9,94\% pada variabel kecepatan perkecambahan (Tabel 3), dan $8,11 \%$ pada variabel indeks vigor (Tabel 4) dibandingkan dengan varietas Grobogan.

\section{KESIMPULAN}

Berdasarkan hasil penelitian, dapat disimpulkan bahwa:

1. Viabilitas benih varietas Burangrang tinggi yang ditunjukkan tingginya kecepatan perkecambahan dan indeks vigor. Viabilitas benih varietas Grobogan tinggi yang ditunjukkan tingginya bobot kering kecambah normal.

2. Viabilitas benih yang dilembabkan selama 12 jam tinggi yang ditunjukkan tingginya kecepatan perkecambahan dan indeks vigor.

Tidak terdapat perbedaan viabilitas benih yang dilembabkan atau yang tidak dilembabkan pada masing-masing varietas.

\section{DAFTAR PUSTAKA}

Agrawal, R. L.1980. Seed Technology. Oxford and IBH Publishing. New Delhi, Bombay, Calcuta. 93 p.

Ai, N. S. dan M. Ballo. 2010. Peranan Air dalam Perkecambahan Biji. Jurnal Ilmiah Sains. 10 (2): 190-195.

Anggun. 2016. Pengaruh Waktu Pelembaban pada Vigor Benih Kedelai (Glycine $\max$ [L.] Merrill) Pascasimpan Tujuh Bulan Asal Pemupukan NPK Susulan Saat $\mathrm{R}_{1}$. Skripsi. Universitas Lampung. Lampung. $50 \mathrm{hlm}$. 
Arif, M., M. T. Jan, I. A. Milan, S. A. Khan, P. Hollington and D. Harris. 2014. Evaluating the Impact of Osmopriming Varying with PEG Concentrations and Durations on Soybean. International Journal of Agriculture and Biology. 16(2):359364.

Arisandi, D. 2019. Pengujian Viabilitas 15 Lot Benih Kedelai (Glycine max L.) Setelah Disimpan Selama 12 Bulan. Skripsi. Universitas Lampung. Lampung. $65 \mathrm{hlm}$.

Bewley, J. D. dan M. Black. 1985. Seed Physiology of Development and Germination. Plenum Press. New York. 367 p.

Copeland. L.O. and M.B. Mc Donald. 2001. Principles of Seed Science and Technology. United States of America. London. 467 p.

Girolamo, G. D and L. Barbanti. 2012. Treatment Conditions and

Biochemical Processes Influencing Seed Priming Effectiveness. Italian Journal of Agronomy. 25(7):178-188.

Harrington, J.F. 1994. Seed Storage and Longevity: Seed Biology. In Ed T. T. Kozlowsky. Academic Press New York. 795 p.

Hong, T.D. 2005. A Protocol to Determinate Seed Storage Behaviour IPGRI Technical Bulletin. University of Reading, United Kingdom. 386 p.

Ilyas, S, M. Surahman, R. Saraswati, L. Gunarto, dan T. Adisarwanto. 2003. Peningkatan mutu benih dan produktivitas kedelai dengan teknik invigorasi benih menggunakan matriconditioning dan inokulan mikroba. Laporan Hasil Penelitian. LPPM IPB-PAATP. Bogor. $61 \mathrm{hlm}$.

ISTA. 2007. Seed Science and Technology. International Rules of Seed Testing. International Seed Testing Association. Zurich Switzerland. 125 p.

International Seed Testing Association (ISTA). 2010. Seed Science and Technology. International Rules for Seed Testing. International Seed Testing Association. Zurich. 125 p.

Khan A. A., J. D. Maquire, G. S. Abawi, dan S. Ilyas, 1992. Matriconditioning of Vegetable Seeds to Improve Stand Establisment in Early Field Plantings. Journal of the American Society for Horticultural Science. 117 (1): 41-47.

Kuswanto, H. 2003. Teknologi Pemrosesan, Pengemasan, dan Penyimpanan Benih. Kanisius. Yogyakarta. $237 \mathrm{hlm}$.

Mugnisjah, W. Q., A. Setiawan, Suwarto, dan C. Santiwa. 1994. Panduan Praktikum dan Penelitian Bidang Ilmu dan Teknologi Benih. PT Raja Grafindo Persada. Jakarta. 264 hlm.

Mugnisjah, W. Q.2001. Pengantar Produksi Benih. Rajawali Press. Jakarta.

Munifah, S. 1997. Pengaruh vigor awal benih dan priming terhadap viabilitas dan produksi benih kedelai (Glycine $\max ($ L.) Merr.). Skripsi. Faperta IPB. Bogor. $50 \mathrm{hlm}$.

Nurmauli dan Y. Nurmiaty. 2010. Studi Metode Invigorasi pada Viabilitas Dua Lot Benih Kedelai yang Telah Disimpan Selama Sembilan Bulan. Jurnal llmu Pertanian Indonesia. 15(1):20-24. 
Powell, A. A. 1998. Seed Improvement by Selection and Invigoration. Journal Scientia Agricola. 55:126-133.

Rusmin, D. 2007. Peningkatan Viabilitas Benih Jambu Mete (Anarcadium occidentale L.) Melalui Invigorasi. Jurnal Perkembangan Teknologi Tanaman Rempah dan Obat. (1): 56-63.

Sadjad, S. 1993. Dari Benih kepada Benih. PT Gramedia Widiasarana. Jakarta. $145 \mathrm{hlm}$.

Sadjad, S. 1994. Kuantifikasi Metabolisme Benih. PT Gramedia Widiasarana. Jakarta. $145 \mathrm{hlm}$.

Sadjad, S., E. Murniati, dan S. Ilyas. 1999. Parameter Pengujian Vigor Benih. PT Grasindo. Jakarta. 186 hlm.

Saryoko. 2011. Sistem Penyedian Benih dan Teknologi Invigorasi untuk Mendukung Ketersediaan Benih Kedelai Bermutu di Provinsi Banten. Tesis. Institut Pertanian Bogor. 9 hlm.

Sivasubramaniam, K. R. Geetha, K.Sujatha, K. Raja, A. Sripunitha and R. Selvarani. 2011. Seed Priming: Triumphs and Tribulation. Madras Agricultural Journal. 98:197-209.

Sutopo, L. 1985. Teknologi Benih. Rajawali. Jakarta. 247 hlm.

Sutopo, L. 2012. Teknologi Benih. Fakultas Pertanian UNBRAW. Jakarta. 237 hlm.

Syaiful, S. A., M. A. Ishak, N. E. Dungga, dan M. Riadi. 2012. Peran conditioning benih dalam meningkatkan daya adaptasi tanaman kedelai terhadap stres kekeringan. Laporan Penelitian. Universitas
Hasanudin. Makassar. 70 hlm.

Tatipata, A. 2008. Pengaruh Kadar Air Awal, Kemasan dan Lama Simpan Terhadap Protein Membran dalam Mitokondria Benih Kedelai. Buletin Agronomi. 36 (1): 8-16.

Widajati, E. 1999. Deteksi vigor biokimia dan vigor fisiologi untuk fenomena pemulihan vigor pada tingkat awal deteriorasi dan devigorasi benih kedelai (Glycine max (L.) Merr.) melalui metode invigorasi. Disertasi. Institut Pertanian Bogor. Bogor. $100 \mathrm{hlm}$

Widajati, E., E. Murniati, E. R. Palupi, T. Kartika, M. R. Suhartanto, dan A. Qadir. 2013. Dasar Ilmu dan Teknologi Benih. IPB Press. Bogor. $274 \mathrm{hlm}$.

Yuanasari, B. S., N. Kendarini, dan D. Saptadi. 2015. Peningkatan Viabilitas Benih Kedelai Hitam (Glycine max L. Merr) melalui Invigorasi Osmoconditioning. Jurnal Produksi Tanaman. 3 (6): 518-527.

Desis, K. (2015). Seleksi Berbasis Kuantitatif Trait Loci (Qtl) Sebagai Alternatif Seleksi Berbasis Varietas Pada Tanaman Padi Dataran Rendah Yang Ditanam Di Lahan Organik. Jurnal Inovasi Pembangunan Volume 03 No. 3.

Sri, W. (2016). Analisis Seleksi Jagung Manis Seleksi Jalur Bebas Sebagai Alternatif Seleksi Hibrida F1. Jurnal Inovasi Pembangunan Volume 03 No. 3. 
Halaman Kosong 